Reprinted from: J. THIEDE and E. SUESS (Eds.): Coastal Upwelling: Its sediment Record. Part B: Sedimentary Records of Ancient Coastal Upwelling.NATO Conference Series, Series IV: Marine Sciences, Plenum Press, New York and London, 1983

\title{
THE MODERN UPWELLING RECORD OFF NORTHWEST AFRICA
}

\author{
Dieter R. Fütterer \\ Geologisch-Paläontologisches Institut \\ Olshausenstrasse $40-60, D-2300$ Kiel \\ Present Adaress: \\ Alfred-Wegener-Institute for Polar Research \\ Columbus Center \\ D-2850 Bremerhaven \\ Federal Republic of Germany
}

ABSTRACT

Several biological and geochemical incicators have been suggested to characterize coastal upwelling processes and to document them in the underlying sediments. These criteria apparently work well in the intensive coastal upwelling regimes off Peru and Namibia. Surface sediments from shelf and slope of the northwest African coastal upwelling area between Cape Bojacor, at about $26^{\circ} \mathrm{N}$, and the Casmance River, at about $13^{\circ} \mathrm{N}$, were examined to evaluate the fate of potential biological vpwelling indicators in a moderate upwelling regime. Off northwest Africa no textural upwelling indicators were found in shallow shelf sediments directly beneath the upwelling centers. Due to oceanographic conditions they are rather winnowed out, transported beyond the shelf edge and dispersed on the continental slope by near-bottom currents or grain-by-grain downslope transport. During this transfer, potential upwelling indicators become altered or entirely destroyed by passing through various "filtering" mechanisms. Modern coastal upwelling conditions off northwest Africa are, therefore, not recorde' in the underlying shelf sediments and are only badly documented in the adjacent slope sediments. This suggests that simple sediment camponent analyses may be misleading if used as the only tool to reconstruct paleoceanographic conditions.

\section{INTRODUCTION}

Coastal upwelling systems have for a long time attracted increasing attention as areas of high biological procuction not only 
from oceanographers and biologists but from geologists as well. This interest results from different causes, however; the main geological question is: "Do the sediments underlying an upwelling system reflect the processes occurring in the upwelled water mass by having characteristic facies patterns which can be recognized in the fossil record?" If the answer is "yes", then we would have an ideal tool to reconstruct special paleoceanographic conditions and environments from the fossil record.

The process of coastal upwelling develops when the wind-driven, elongshore surface water currents result in an offshore Eman transport. This flow is compensated for by transport of nutrient-rich subsurface water into the euphotic layer where optimal light conditions for phytoplankton favor an increasing biological activity. The main characteristics that distinguish coastal upwelling areas from other regions of the ocean are: (1) High nutrient content which causes an enhanced primary production, (2) lowered temperatures at the sea surface, and (3) lowered oxygen content in the surface layer (Barber and Smith, 1981). These upwelling characteristics produce a unique ecosystem, the remains of which should be documented in some way or other in the underlying sediments. The direct relation, however, is strongly complicated by the fact that the upwelling processes are merely short-termed events in the order of days or weeks, including additional seasonal shifts, whereas the sediments show a long-termed memory in the order of hundreds to thousands of years. Depending on the sedimentation rate, only very mixed and averaged oceanographic signals are likely to be preserved in the sediments.

Various sedimentary parameters are discussed in detail as upwelling indicators by Diester-Haass (1978). She suggests that several biological and chemical indicators, like high biogenic opal content, abundant fish debris, low plankton/benthos ratios of foraminifers, presence of cool water foraminifers, high content of organic watter, etc., characterize the sedimentary record of upwelling processes. But, more precisely, such indicators do not stand for "upwelling" alone, but for water masses different from the nearby normal oceanic waters. In fact, these indicators tell us about the temperature, salinity, oxygen or nutrient content, but their individual presence does not necessarily prove that upwelling has occurred.

The main aim of the present paper is to describe the modern sedimentary record along the northwest African continental margin off the Saharan desert in order to detect the influence of the northwest African coastal upwelling system. Mainly, textural parameters and sediment constituents are considered; geochemical aspects, like phosphorite genesis, minor metals and isotope studies, are excluded, as are paleontological species analyses. The investigated sediments come from sample transects across the continental margin between cape Bojador, at about $26^{\circ} \mathrm{N}$, and the Casamance River, at about $13^{\circ} \mathrm{N}$ (Fig. 1). 
MORPHOIOGICAI SETTING

The shelf in the stucied area is generally narrow, about 45-55 $\mathrm{km}$ wide, with the exception of the Banc d'Arguin. There the shelf is about $140 \mathrm{~km}$ wide and $c a n$ be divided into a broader, shallow inner shelf with less than $20 \mathrm{~m}$ water depth, and a deeper outer shelf area. In both areas the shelf break occurs at water depths of $110-150 \mathrm{~m}$ (Piessens and Chabot, 1977).

The continental slope is about $45 \mathrm{~km}$ wide with an average inclination of between $2^{\circ}$ and $3^{\circ}$. Numerous small and several larger canyons are located off the shelf edge throughout the area, and par-

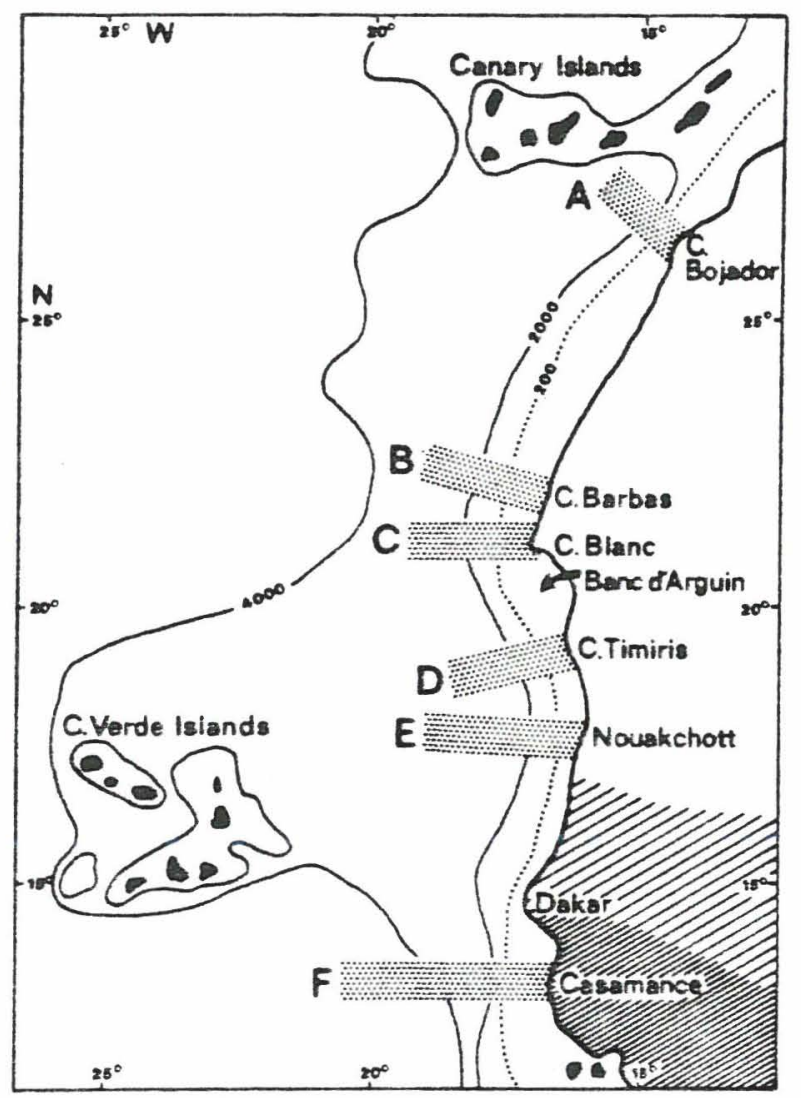

Fig. 1. Northwest African continental margin showing location of investigated sample lines $(A, B=$ "Meteor" cruise $25-1971 ; C=$ "Meteor" cruise 39-1975; D,E,F = "Valdivia" cruise 10-3-1975). Densely hatched continental area = winter-dry tropical savannah; widely hatched = winter-dry hot steppe; blank = dry, hot region of Saharar desert. 
ticularly south of Cape Bojador (Rust and wieneke, 1973; Seibold and Hinz, 1974; Arthur et al., 1979), and off the Banc d'Arguin, where one canyon may even be traced on the shelf as well (Bein and Futterer, 1977). Very fine-grained mud blankets found in some of these canyons appear to indicate that there are no strong currents at present.

THE UPWEIIING SYSTEM AND OCEANOGRAPHIC SETTING

off northwest Africa, coastal upwelling is caused by a complex interaction of the nearly longshore Trade winds and the southward flowing cool Canary Current. The Ekman principle results in a seaward transport of the surface water layer. The nearshore surface layer is replaced by nutrient-rich water masses upwelled from a poleward undercurrent that prevails over the upper slope and at some places on the outer shelf (Mittelstaedt and Hamann, 1981). Upwelling is year round from $20^{\circ} \mathrm{N}$ to $25^{\circ} \mathrm{N}$, and it is most intensive off Cape Blanc (Fig. 2A). Seasonal upwelling occurs during the winter south to Sierra Leone, and in summer farther north up to Morocco and portugal.

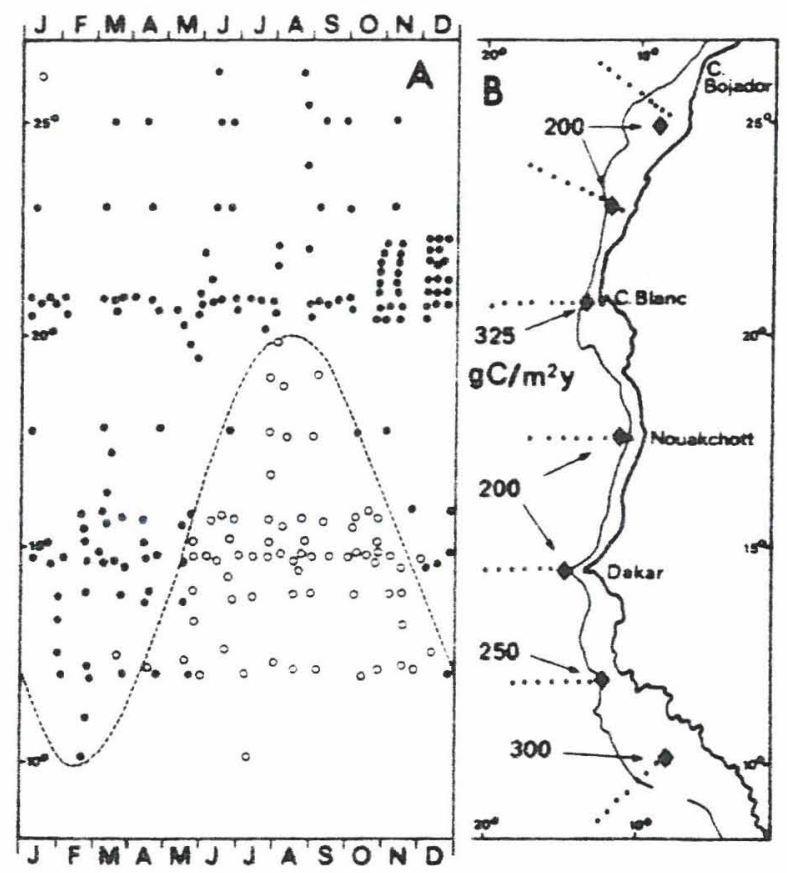

Fig 2. Variation of upwelling off northwest Africa in space and time (A) (dots = observed upwelling at given time) and maximum values for annual primary production (B); simplified from Schemainda, Nehring and Schulz, 1975. 


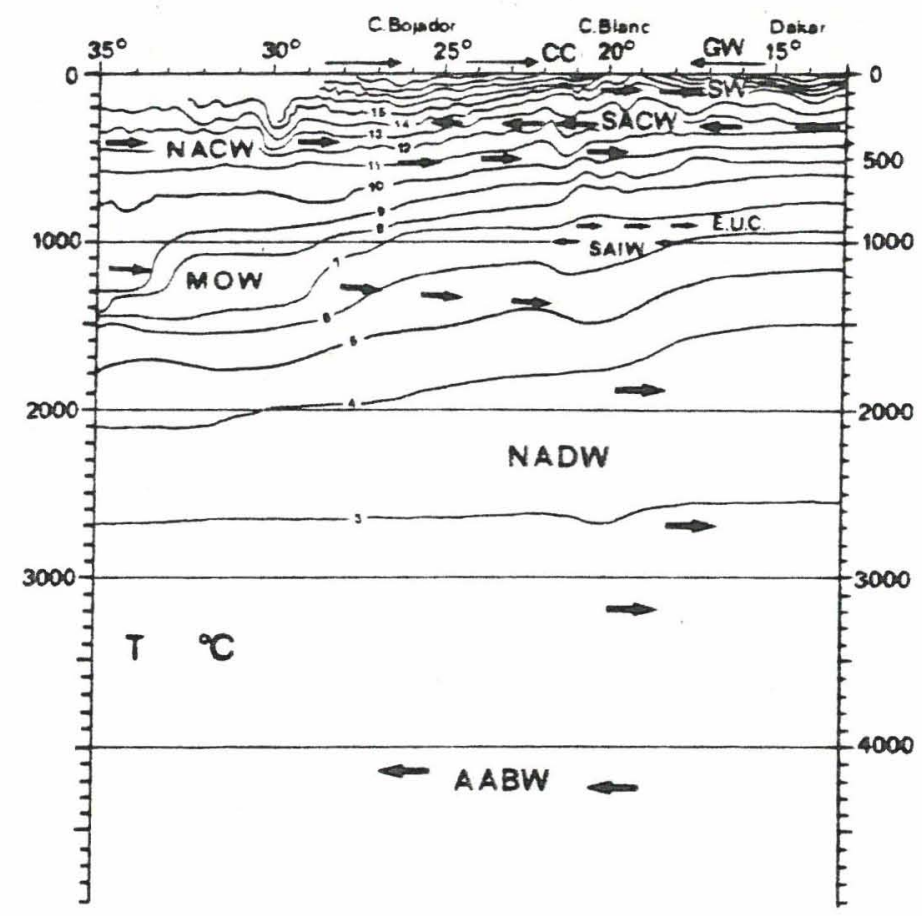

Fig. 3. Stratification of bottom water temperature and ocean circulation (arrows) near the bottom along the northwest African continental margin. $A A B W=$ Antarctic Bottom Water, NADW = North Atlantic Deep water, MOW = Mediterranean outflow water, SAIW = South Atlantic Intermediate water, E.U.C. = Equatorial Undercurrent, NACW = North Atlantic Central Water, $\mathrm{SACW}=$ South Atlantic Central Water, SW = Surface water, $C C$ = Canary Current, $G W=$ Guinea Water Mass; simplified from Lutze, 1980 and Sarnthein et al., 1982; depth in (m).

The maximum values for the annual primary production in that region show a similar pattern (Fig. 2B). Highest values off Cape Blanc coincide with year round upwelling; decreasing values to the south are due to seasonal upweliing. The higher values off sierra Leone are caused by an aditional nutrient input by rivers. The relatively low values north of Cape Blanc can be explained by differences in stratification of the oceanographic circulation system (Fig. 3). Off Cape Blanc, at about $21^{\circ} \mathrm{N}$ to $23^{\circ} \mathrm{N}$, the north flowing undercurrent of South Atlantic Central water (SACW) provides a characteristically nutrient-rich source water for this upwelling region. North of about $23^{\circ} \mathrm{N}$ the SACW is replaced by the relatively nutrient poor North Atlantic Central water (NACW) as the main source for the upwelìed waters (Frağa, 1974; Codispoti and Friedrich, 1978). These principal differences in nutrient content of the source waters feeding the upwelling system are most likely the reason for the corresponding regional differences in primary production. 
The main area of nearshore upwelling is confined to a water depth in the range of $50 \mathrm{~m}$ or less on the midale or inner shelf. However, depending on the strength of the local winds, the upwelling system may extehd as far as $100 \mathrm{~km}$ offshore, which is twice the shelf width (Mittelstaedt, Pillsbury and Smith, 1975). The system is fed by an onshore compensation flow with water from 100-200 in depth. strong onshore and alongshore bottom currents result from this compensation flow, preventing the accumulation of fine-grained sediments (Barber and Smith, 1981).

\section{SEDIMENT DISTRIBUTION}

The upwelling conditions briefly sumarized above should be documented in some way or other in the underlying sediments. However, if we look at the sediments on the shallow shelf directly beneath the upwelling area, no indication of the upwelling conditions are observed.

The sediment distribution along the northwest African continental margin is mainly controlled by biological production of skeletal material and by two different mechanisms supplying terrigenous material: (1) an eolian input of carbonate-free or carbonate-poor detritus by Harmattan and Trade Hinds respectively, and 2) a fluvial input of fine-grained muds in the southern part of the area by the Senegal River. The overall sediment distribution pattern reflects these predominant supply mechanisms (Fltterer, 1980). A general view of the diverse sedimentary lithofacies present in the surface sediments of that area is given by the carbonate distribution pattern (Fig. 4).

The shelf area off Cape Blane which is the most productive upwelling area, and the shelf to the north is covered far beyond the shelf edge by coarse, in large part relict, molluscan and algal carbonate sands. Downslope, the carbonate content rapidly decreases to minimum values on the lower continental slope, and increases again on the continental rise. Farther to the south the carbonate content on the shelf decreases as the content of coarse-grained guartz increases. Fine-grained shelf muds are confined exclusively to the pro-delta area of the Senegal River. There is no indication on the northwest African margin of a shallow water mud lens like those reported from the shelf or upper slope of the upwelling areas off Namibia and Peru, respectively. This becomes further evident by a closer look at the grain-size distribution of the sediments. Off cape Barbas, at about $22^{\circ} \mathrm{N}$ (Fig. 5), a very coarse-grained sand covers the shelf and extends far beyond the shelf edge onto the upper slope. The sand shows a distinct, continuous shift to smaller grain sizes with pronounced maxima in the silt-size range with increasing water depth. This striking silt-size maximum is even more obvious farther to the south, off Cape Timiris at $19^{\circ} \mathrm{N}$ (Fig. 6), and off Nouakchctt at about $18^{\circ} \mathrm{N}$. These areas are located beneath the center of the 


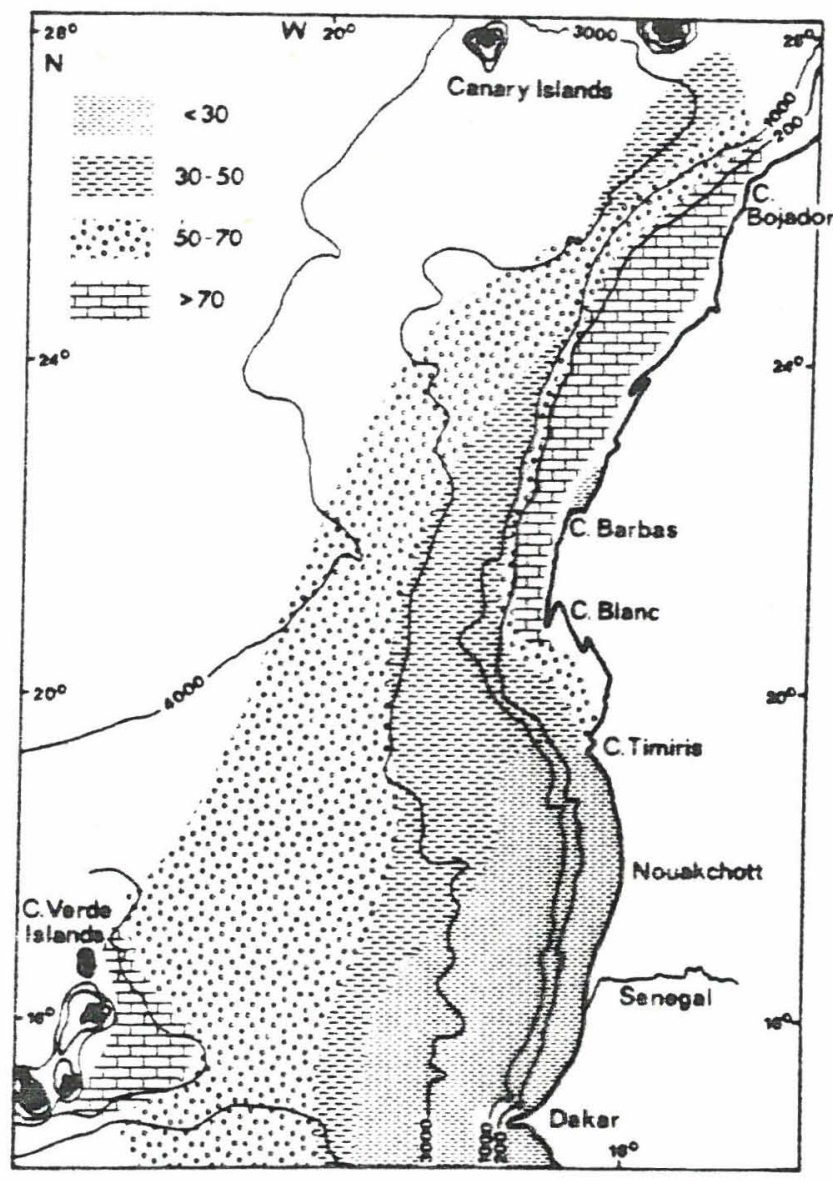

Fig. 4. Carbonate content in weight percent of surface sediments off northwest Africa.

eolian dust supply from the Saharan desert which is assumed to cause this characteristic grain size distribution. There is a sharp decrease in sand content, or a sharf increase in silt content, between 300-500 m water depth south of Cape Blanc, and at somewhat greater water depth of 500-800 $\mathrm{m}$ off and north of Cape Blanc. This pattern may be explained by the deflection to the west of the south flowing Canary current system off Cape Blanc. This current may be deep enough and strong enough to prevent sedimentation of fine-grained material on the upper slope off and north of Cape Blanc, whereas the north flowing undercurrent originating from SACW and centered at 150-400 In water depth shapes the slope south of Cape Blanc.

We interpret the grain size distributions as reflecting ocearic currents and wave action which irtensively retard sedimentation on 


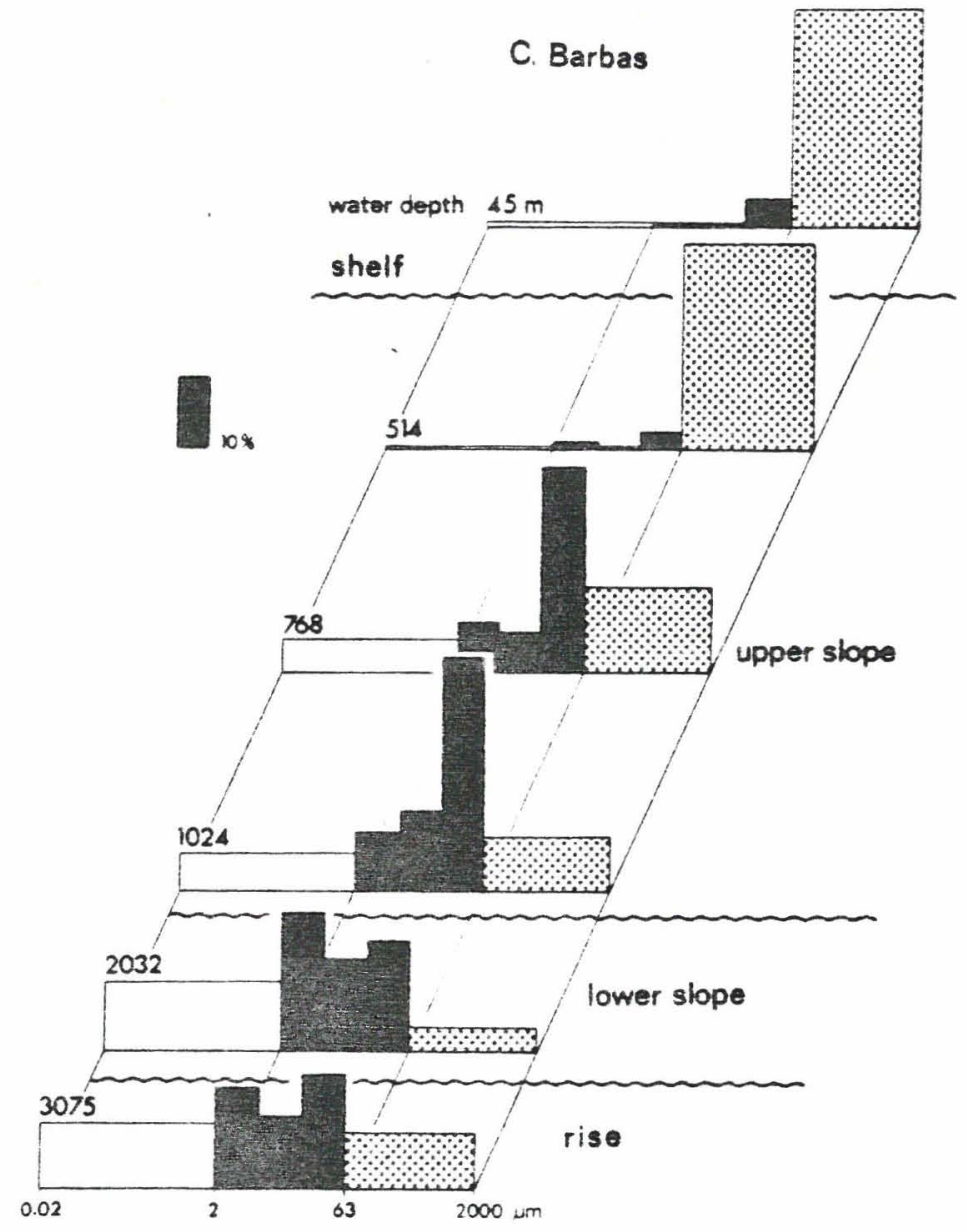

Fig. 5. Grain size distribution of surface sediments off cape Barbas (sample line B in Fig. 1).

the shelf and upper continental slope at present. These agents may even be strong enough to rework and erode the shelf sediments in places. As a result, a substantial fraction of the sediment supplied to the shelf crosses the shelf edge and is transported downslope in suspension by a nepheloid layer system or grain-by-grain. The latter mechanism accounts for the abundant occurrence of relatively larger shallow water constituents in deeper waters downslope (Bein and Futterer, 1977, Fütterer, 1980).

At this point we have to state that at present no record of upwelling can be recognized in the modern sediments directly underlying the upwelling area on the shelf and upper slope. All upwelling 


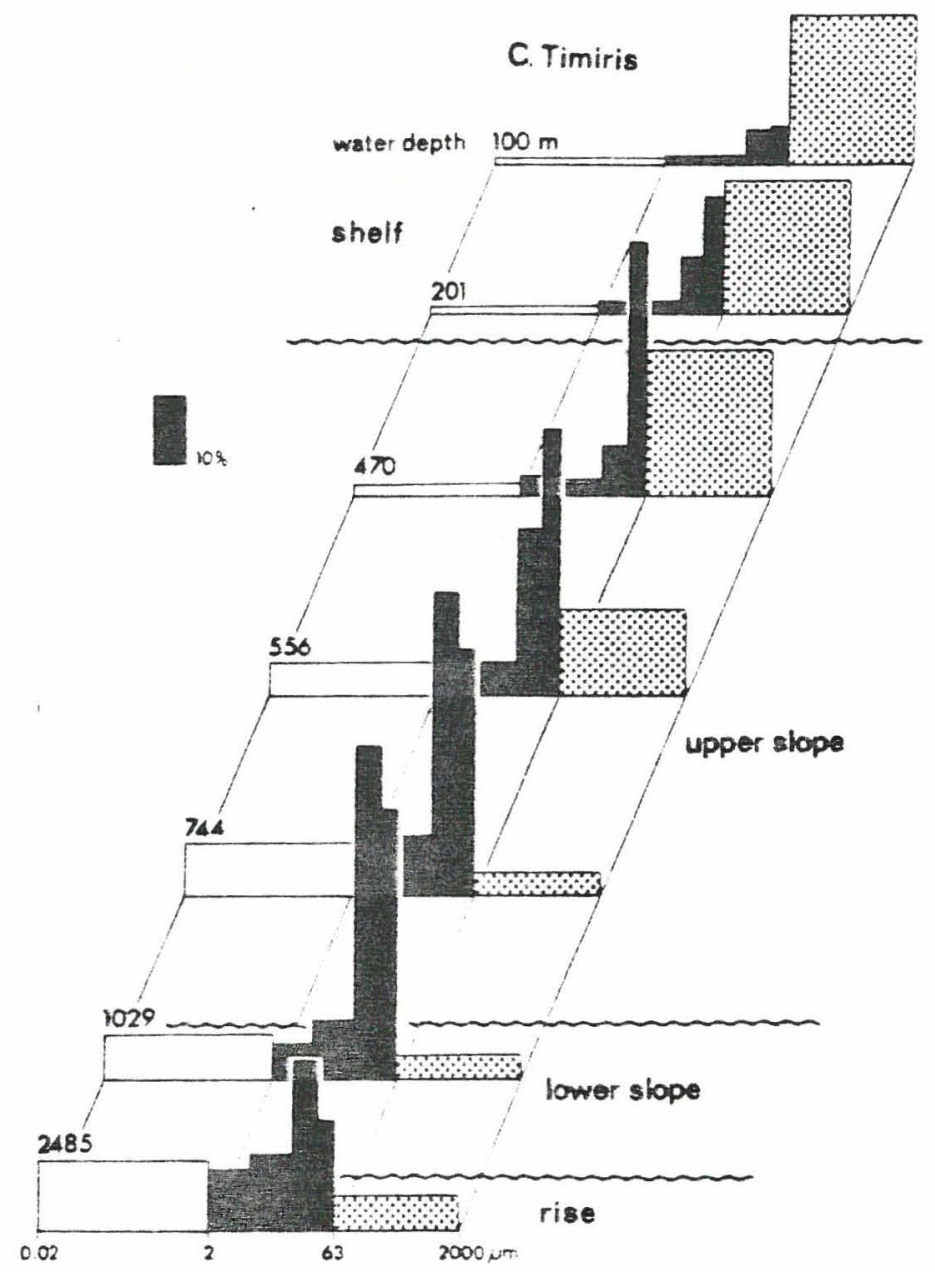

Fig. 6. Grain size distribution of surface sediments off cape Timiris (sample line $D$ in Fig. I) showing prominent silt sized maximum caused by high eolian input.

indicators (Diester-Haass, 1978) have disappeared, and for the most part have been transported beyond the shelf edge and spread over the deeper continental slope and rise.

\section{SEDIMENT CONSTITUENTS}

To trace the shallow water material farther downslope, a guantitative aralysis of the sediment components has been carried out by which the conditions described above become evident in more detail 
(Figs. 7 and 8). The contrast in carbonate content between the areas off and north of Cape Blanc, and those south of the Banc d'Arguin, is clearly demonstrated. It is caused by different abundances of relict sediment constituents, biogenic carbonate prevailing in the north (Cape Blanc, Fig. 7) and terrigenous quartz dominating south of the Banc d'Arguin (off Cape Timiris, Fig. 8). Benthic carbonates other than foraminifers ("Oc" in Figs. 7 and 8), decrease in quantity from the shelf downslope and consist mainly of molluscs and echinoderms. however, other benthic constituents like ostracods, siliceous sponges, red algae, ascidian spicules, octocorals and boring chips of boring sponges are present as well but in very small numbers only. The last four of these constituents can be used as downslope transport indicators. Depending on their size, these tracer particles are transported downslope to different depths of final deposition. The depth of main deposition is centered at the mid-slope below $1000 \mathrm{~m}$.

As the benthic constituents decrease downslope, the planktonic constituents, mainly foraminifers and coccoliths, increase. The plankton to benthos ratio of foraminifers has been suggested by Diester-Haass (1978) to indicate regions influenced by upwelling. But within the modern surface sediments off northwest Africa, no significant changes in this ratio are apparent.

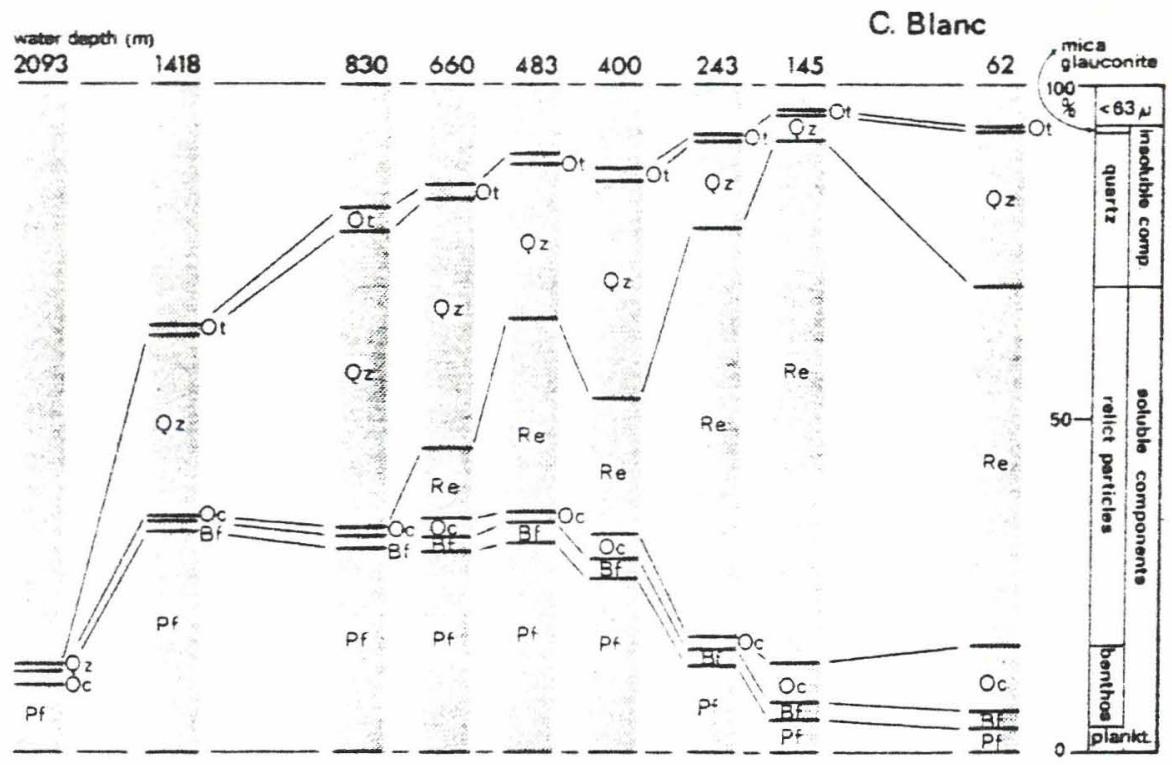

Fig. 7. Composition of coarse-grained $(>63 \mu \mathrm{m})$ sediment components of surface sediments off Cape Blanc (sample line C in Fig. 1). Pf = planktonic foraminifers, $B f=$ benthic foraminifers, $O C=$ other biogeneous carbonate grains (mainly molluscs and echinoderms), $R e=$ relictic biogenic waterial, $Q z=$ quartz, ot = other terrigeneous material (mainly mica and glauconite). 
Radiolarians and distoms occur very rarely in the slope sediments and are not abundant enough to be depicted as compositional units in Figs. 7 and 8 . Both of these components are believed to indicate increased fertility. Diester-Haass (1977) found radiolarian to plarktonic foraminiferal ratios to be highest in the center of the actual upwelling area off Cape Blanc, and used this ratio to propose increased upwelling during the whrm in this region. The abundance of radiolarian tests in the surface sediments in this area, however, seems to be linked more to the high nutrient content of subsurface waters, and reflects the distribution pattern of the SACW (in contrast to the NACW) rather than to an upwelling process (Labracherie, 1980). Diatom frustules or fragments likewise are extremely rare in the slope sediments and do not show any significant distribution pattern. The low abundance of diatoms in the sediments may be explained by the observation that most of the dominant species living in this upwelling system are only weakly silicified, a fact which favors their dissolution during settling and at the sea bottom (Richert, 1975). A detailed survey on the content of bulk biogenic opal in the slope sediments has been carried out by Roopmann (1979; 1981). As expected, the opaline silica content is very low (Fig. 9) showing relatively higher values nearshore. There is no significant latitudinal variation, although there may be slight maxima off cape Blanc

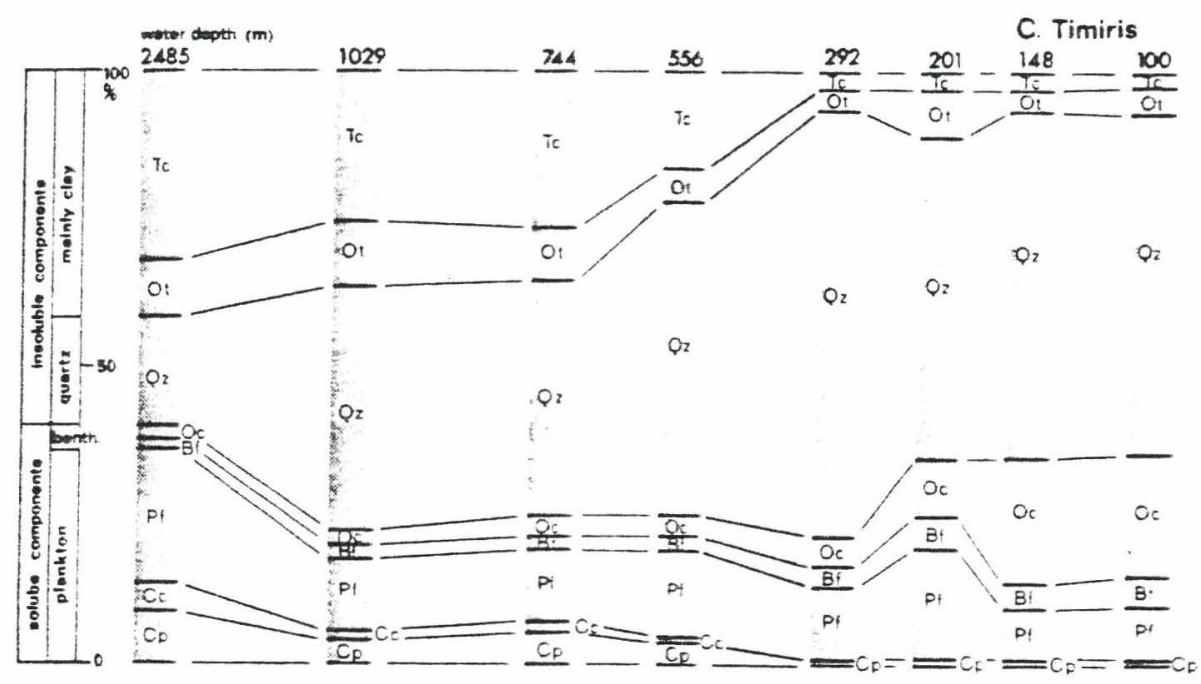

Fig. 8. Quantitative composition of sediment components off Cape Timiris (sample line $D$ in Fig. 1, total sample). $C P=<2 \mu m$ carbonate particles (derived mainly from coccoliths), $C c=$ silt-sized coccoliths, $\mathrm{Pf}=$ planktonic foraminifers, $\mathrm{Bf}=$ benthic foraminifers, $O C=$ other biogenic carbonate grains (mainly molluscs and echinoderms), $Q Z=$ quartz, $O t=$ other terrigeneous material (mainly mica and glauconite), $T C=<2 \mu \mathrm{m}$ terrigeneous particles (mainly clay). 
and Cape Barbas, and south of Dakar. With our background knowledge of the existing oceanographic conditions, we might interpret this pattern as upwelling induced off Cape Blanc, and river influenced south of Dakar. However, despite the low abundance of diatoms, fresh water diatoms, e.g., Melosira gramlato which is a strongly silicified species and well known from eolian dust samples, are relatively aburdant here (Futterer, 1980). This implies that the small maxima of biogenic opal in the area off Cape Blanc reflects the input of eolian dust rather than increased fertility induced by upwelling. In contrast, biogenic opal is abundant in the very shallow and protected Baie du Levrier, on the innermost part of the Banc d'Arguin (Roopmann, Sarnthein and Schrader, 1978). Here the upwelling triggered plankton production from the outer shelf is moved inshore by currents and trapped in a small coastal basin.

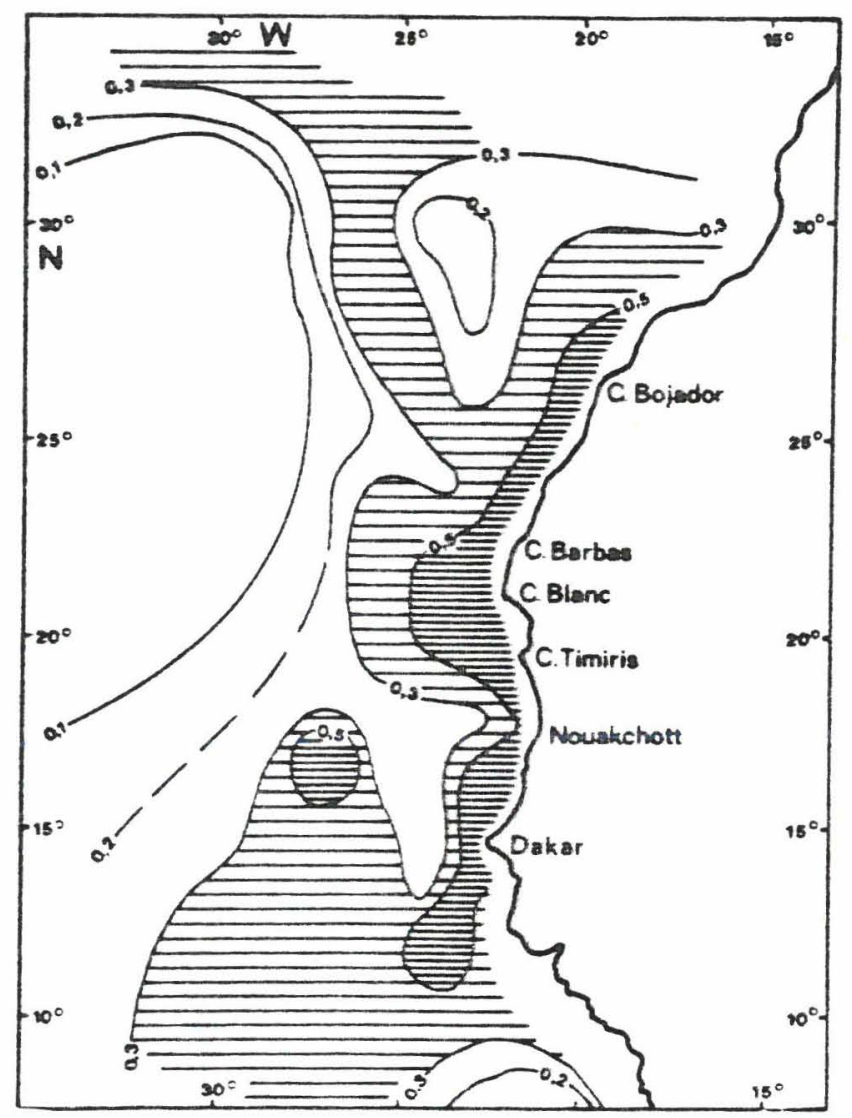

Fig. 9. Concentrations of biogenic opal (weight percent of $>6$ $\mu m$ fraction) in the bulk carbonate-free surface sediments off northwest Africa; modified from Koopmann, 1979. 
The pattern of distribution of fish debris, which is another generally accepted indicator for nutrient-rich waters, is like that of diatoms. Fish debris is only occasionally present in the slope sediments, but is enriched in the shallow water of the Baie du Levrier (Koopmann et al., 1978). The organic matter content of the sediments is only a very rough indicator of higher fertility or productivity and, hence, of upwelling. It depends in a complex way on grain-size, sedimentation rate, and organic matter production (Mller and Suess, 1979). On the continental slope off northwest Africa there are two areas of abundant organic matter (Fig. 10): 1) at about $16^{\circ} \mathrm{N}$ off the Senegal River, and 2) at about $21^{\circ} \mathrm{N}$ off cape Blanc, which is the main area of modern upwelling activity. Both areas are at water depths of about $1000 \mathrm{~m}$ to $2000 \mathrm{~m}$, which is where the maximum deposition of fine-grained material takes place and forms a mid-slope mud lens. The high organic matter content of this midslope mud lens at about $21^{\circ}-22^{\circ} \mathrm{N}$ is most probably caused by the coastal upwelling system off Cape Elanc, whereas farther to the south, at about $15^{\circ}-16^{\circ} \mathrm{N}$, it is due to an increase in fertility caused by river input of nutrients. From the distribution of bulk organic matter alone it is impossible to tell which of these two areas is upwelling or river controlled. Better results come from organic geochemistry showing highest marine organic matter contribution (with high $\mathrm{H} / \mathrm{C}$ ratios) off Cape Blanc, and highest terrestrial organic matter contribution (with low $\mathrm{H} / \mathrm{C}$ ratios) off the senegal River, in the mid-slope mud belt (pelet, 1979).

Other arguments for differentiating between these environments come from textural parameters. The fluvial input of the senegal River is characterized by a basically bimodal grain size distribution with an excess of clay sizes (Sarnthein et al., 1982), whereas the eolian input off Cape Blanc is dominated by silt sizes. Similar

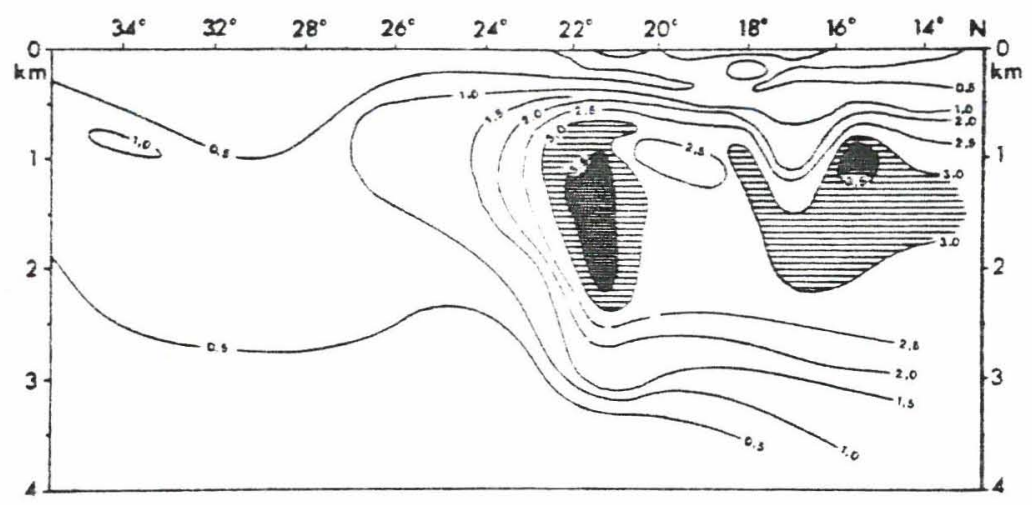

Fig, 10. Distribution of orgaric carbon (as weight percent) in surface sediments along the northwest firican continental margin; modified from sarnthein et al., 1982. 
amounts of organic matter to those in the mid-slope mud lens are found in the fine-grained shallow water prodelta muds of the senegal River (Domain, 1977), which are associated with considerable amounts of plant debris.

Intensive calcium carbonste dissolution along the continental margin is indicated by the disappearance of pteropod shells with increasing depth (Diester-Haass and Muller, 1979; Fitterer, 1980). The critical depth, assumed to be the aragonite compensation depth (ACD), shallows from $2500 \mathrm{~m}$ at the Cape Verde Rise, and from $2000 \mathrm{~m}$ on the continental slope off Cape Bojador, to about $500 \mathrm{~m}$ approaching the slope off Cape Blanc (Futterer, 1980). This coincides with increased fragmentation of foraminiferal tests on the slope off cape Blanc (Diester-Hass and Miler, 1979).

\section{CONCLUSIONS}

From textural and compositional analyses of the surface sediments underlying the coastal upwelling area off northwest Africa, we can conclude that modern coastal upwelling conditions are not recorded in the underlying sediments of the shelf region.

In comparison with other upwelling areas, such as off oregon or Peru, where a shallow water upwelling facies is present in the sediments, the unique conditions off northwest Africa become evident. The shelf width and cross-shelf bathymetry (Fig. 11) are such that the poleward undercurrent is centered over the upper slope, only occasionally affecting the outer shelf (Barber and Smith, 1981; Mittelstaedt and Hamann, 1981). During upwelling, the onshoreoffshore and alongshore compensation flows originating from undercurrent water masses create strong bottom currents which prevent sedimentation of fine-grained material on the shelf. Because of the steeper shelf gradient off Oregon and Peru, these currents are well above the sea floor in the water column, allowing fine-grained material to accumulate in a shallow water mud lens. Morphological and oceanographic conditions like those of oregon and Feru today were present off northwest Africa during times of glacially lowered sea level, when the shelf was narrow and the upwelling system was more confined to the shelf edge. Under these conditions a shallow water mud lens could have formed on the upper slope, enabling better preservation and a more conplete sequence of geological signals from which a glacial upwelling environment off northwest Africa can be interpreted.

Fine-grained sediments rich in opaline silica, fish debris or organic matter, indicative of present day upwelling, are trapped and preserved only locally in small nearshore basins on the shelf, such as in the Baie du Levrier of the inner Banc d'arguin. Most of the upwelling-derived material is transported beyond the shelf edge 

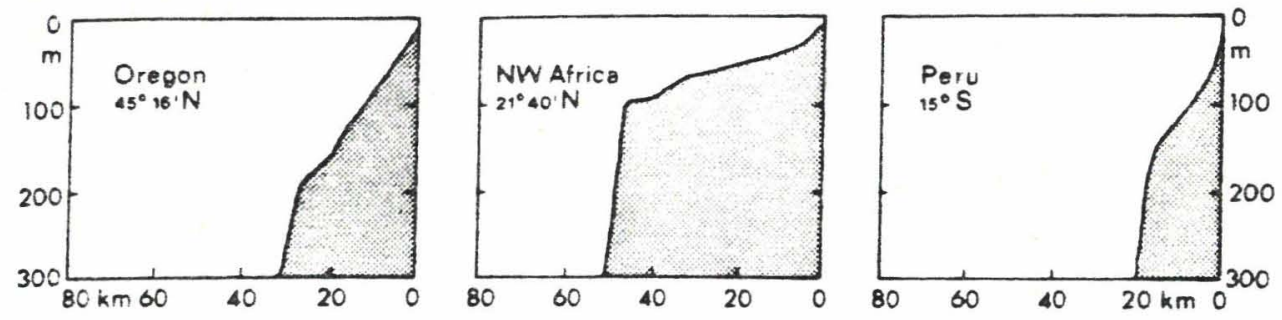

Fig. 11. Cross-shelf bathymetry of the upwelling regions off Oregon, Peru, and northwest Africa; modified from Barber and Smith, 1981. By permission from Aralysis of Marine Ecosystems, Copyright (c) Academic Press, Inc.

and spread over the continental slope. During this transport the material has to pass diverse filter mecharisms which affect the various components in different ways. Much of the organic matter becomes oxidized, whereas most of the skeletal material is fragmented mechanically during bottom current transport on the shallow shelf or destroyed by dissolution during settling or at the sediment-water-interface. On the slope, the remaining material is transported farther downslope by mechanisms that we do not yet fully urderstand. Final accumulation takes place in a mid-slope mud lens at water depths below $1000 \mathrm{~m}$. The upwelling "memory" of these slope sediments, however, is weak and in many cases ambiguous (i.e., may be attributed to factors other than upwelling).

From the point of view of the geologists who would like to reconstruct paleo-environments from fossil records, it has to be stated that the textural and compositional signals obtained from the modern slope sediments off northwest Africa are not clear enough to deduce an upwelling environment in the overlying water column without background information from modern oceanography.

\section{ACKNOHLEDGEMENTS}

I have to thark my colleagues G. Ganssen, P. Muller and M. Sarnthein for numerous valuable discussions and helpful advice. N. Exon, Canberra City, and $c$. Sumerhayes, Houston, criticaily reviewe 3 the manuscript and gave suggestions for its improvement. This work was partially supported by the Deutsche Forschungsgemeinschaft.

\section{REFERENCES}

Arthur, M.A., von Rad, U., Cornford, C., McCoy, F.w., and Sarnthein, M., 1979, Evolution and sedimentary history of the Cape Bojador continental margin, northwestern Africa, in: "Initial Reports DSDE," 47, Part I, U. vor. Rac, H.E.F. Pyar, et al., eds., U.S. Government Printing office, riashington, 773-816. 
Barber, R.T. and Smith, R.I., 1981, Coastal upwelling ecosystems, in: "Aralysis of Marine Ecosystems," A.R. Longhurst, ed., Academic Press, London, 31-68.

Bein, A. and PUtterer, D., 1977, Texture and composition of continental shelf to rise sediments off the northwestern coast of Africa: An indication for downslope transportation, "Meteor"Forschungs-Ergebnisse, C27:46-74.

codispoti, I.A. and Friedrich, G.E., 1978, Local and mesoscale influences on nutrient variability in the northwest African upwelling region near Cabo Corbeiro, Deep-Sea Research, 25:751-770.

Diester-Haass, I., 1977, Radiolarian/planktonic foraminiferal ratios in a coastal upwelling region, Journal of Foraminiferal Research, $7: 26-33$.

Diester-Hasss, I., 1978, Seciments as indicators of upwelling, in: "Upwelling Ecosystems," R. Boje, and M. Tomczak, eds., SpringerVerlag, Berlin, 261-281.

Diester-Haass, L., and Miller, P.J., 1979, Frocesses influencing sand fraction composition and organic matter content in surface sediments off West Africa $\left(12-19^{\circ} \mathrm{N}\right)$, "Meteor" Forschungs-Ergebnisse, C $31: 21-47$.

Domain, F., 1977, Description de la secimentation fine et des formations rocheuse du plateau continental ouest-africain de $17^{\circ} \mathrm{N}$ a $12^{\circ} \mathrm{N}$, Association senégalese Etude cuatemaire Afrique Bulletin de Iiaison, senégal, No. 50:11-22.

Fraga, F., 1974, Distribution des masses d'eau dans 1'upwelling de Mauritarie, Tkthys, 2:13-52.

Futterer, D., 1980, Sedimentation am Nw-afrikanischen Rontinentalrand: Quantitative Zusarmensetzung und Verteilung der siltfraktion in den Oberfluchensedimenten, "Meteor"Forschungs-Ergebnisse, C33:15-60.

Roopmar, B., 1979, "Saharastaub in den Sedimenten des subtropischtropischen Nordatlantik whrend der letzten 20,000 Jahre," Ph.D. Thesis, Fachbereich Mathematik-Naturwissenschaften, Universityt Kiel, $107 \mathrm{pP}$.

Koopmann, B., 1981, Sedimentation von Saharastaub im subtropischen Nordatlantik whrend der letzten 25,000 Jahre, "Keteor"Forschungs-Ergebnisse, C35:23-59.

Koopman, B., Sarnthein, M., and Schrader, H.-J., 1978, Sedimentation influenced by upwelling in the subtropical Baie du Levrier (West Africa), in: "Upwelling Ecosystems," R. Boje and M. Tomczak, eds., Springer-Verlag, Berlin, 282-288.

Iabracherie, M., 1980, Les Radiolaires temoins de l'evolution hydrologique depuis le dernier maximum glaciaire au large du Cap Blane (Afrique du Nord-ouest), Palaeogeography, Palaeoclimatology, Falaeoecology, 32:163-184.

Lutze, G.R., 1980, Depth distribution of benthic foraminifera on the continental margin off NW Africa, "Meteor"Forschungs-Ergebnisse, C32:31-80. 
Mittelstaedt, E. and Hamann, I., 1981, The coastal circulation off Mauritania. Results of the upwelling experiment "Auftrieb 77" during January and February 1977, Deutsche Hydrographische Zeitschrift, 34:81-118.

Mittelstaedt, E., Pillsbury, D., and Smith, R.I., 1975, Flow pattems in the Northwest African upwelling area. Results of measurements along $21^{\circ} 40^{\prime} \mathrm{N}$ during February-April 1974, JOINT-I, Deutsche Hyarographische Zeitschrift, 28:145-167.

Mller, P.J. and Suess, E., 1979, Productivity, sedimentation rate, and sedimentary organic matter in the oceans - I. Organic carbon. preservation, Deef-Sea Research, 26A:1347-1362.

Pelet, R., 1979, Geotimie organique des sédiments marins profonds au large de la Mauritanie et du Sénégal: Vue d'ensemtle, "Géochimie Organique des sediments Marins Profonds - ORGON III, Mauritanie, senegal, Iles du Cap-Vert", M. Arnould and R. Pelet, eds., Editions du Centre National de la Recherche Scientifique, Paris, 425-441.

Piessens, P. and Chabot, A.G., 1977, Bathymetry and sediments of the Arguin Platforx, Mauritania, west Africa, Memoires de l'Institut géologique de l'Université de Louvain, 29:369-379.

Richert, P., 1975, "Die rumiiche Verteilung und zeitliche Entwicklung des Phytoplanktons mit besonderer Berlicksichtigung der Diatomeen im N.W.-afrikanischen Auftriebswassergebiet," Ph.D. Thesis, Fachbereich Mathematik-Naturwissenschaft, Universitat Kiel, $140 \mathrm{pp}$.

Rust, U. and wieneke, F., 1973, Bathymetrische und geomorphologische Bearbeitung von submarinen "Eirschnitten" im Seegebiet vor Westafrika. Ein methooischer Versuch, Munchener Geographische Abhandlungen, $9: 53-68$.

Sarnthein, M., Pflaumann, U., Thiede, J., Erlenkeuser, H., Futterer, D., Koopmann, B., Lange, H., and Seibold, E., 1982, Atmospheric and oceanic circulation patterns off Northwest Africa during the past 25 miliion years, in: "Geology of the west African Continental Margin," U. von Rad, K. Hinz, M. Sarnthein, and $E$. Seibold, eds., Springer-Verlag, Berlin, 545-604.

Schemainda, R., Nehring, D., and Schulz, S., 1975, Ozeanologische Untersuchungen zum Produktionspotential der nordwestafrikanischen wasserauftriebsregion 1070-1973, Geodatische und Geophysikalische Verbffentlichungen, Reihe IV, Heft 16, Berlin, 88 PP.

Seibold, E. and Hinz, K., 1974, continental slope construction and destruction, west Africa, in: "The Geology of Continental Margins", C.A. Burk and C. I. D: ake, eds., Springer, Berlin, 176196. 